\title{
DEVELOPING GENERIC SCIENCE SKILLS OF PROSPECTIVE TEACHER THROUGH OFFLINE AND ONLINE INTERACTIVE MULTIMEDIA IN PHYSICS LEARNING
}

\author{
Saprudin, Sutarno, Liliasari \\ 1. Khairun University, Department of Physics Education \\ 2. Bengkulu University, Department of Physics Education \\ 3. Indonesia University of Education
}

\begin{abstract}
Generic science skills are basic skills that important to belonging for prospective teacher in Indonesia for the provision them to pursue a career in a wider sector. The aim of this research is to construct offline and online interactive multimedia model that can used to improve generic science skills of prospective teachers. Quasi experimental method with non-equivalent control group design was used and involved students at department of engineering education of one university at Bandung who were taking introductory physics course for offline interactive multimedia and for online interactive multimedia involve the student at department of physics education of one University at Bengkulu City. The data were collected by using generic science skills test. Based on the result of data analyze with SPSS version 16.0 it was found that students who learned by using interactive multimedia which presented by offline or online method was significantly better in improving generic science skills than students who learn with conventional models.
\end{abstract}

Key words: offline Interactive multimedia, Online Interactive multimedia, Generic science skills

\section{Introduction}

Introductory Physics is one of the basic course that learned by physics prospective teachers in the university. One of the reasons that introductory physics is taught in these institutions is the importance of physics as a work discipline that can produce a number of generic science skills for working in a wider range of professions (Brotosiswoyo, 2000). A number of generic science skills that can be grown in physics learning include: 1) direct observation; 2) indirect observation; 3) awareness of the magnitude scale; 4) symbolic language; 4) consistently logical framework; 5) logical inference; 7) causality 8) mathematical modelling; and 9) concept development.

The fact that shown is until now physics is still considered as a difficult subject to be studied by students. One of the factors that may cause the difficulties of studying 
physics are the factors which related with the characteristics of physics context, for example physics is cumulative, abstract, involves many things to learn and requires a good understanding of mathematics (Ornek et al., 2008).

Rapid development of information and communication technology has been demanding and providing opportunities for teacher to develop a learning model by utilizing the media of information and communication technology (Hoban \& Ferry, 2006). The teacher is required to be able to package as attractive as possible so that the lecture material can increase student motivation to learn and also facilitate students to understand the lecture material. One effort that can be done is to use interactive multimedia in learning physics.

Multimedia is a combination of text, sound, image, colour, motion, video with tools (tools) and connections (links) so that users can navigate, interact, work and communicate (FCIT, 2010; Wikipedia, 2010). The use of offline interactive multimedia presented in physics learning can improve the generic science skills of students (Gunawan, 2008; Yahya, 2008; Wiyono, 2009).

The existence of technology development allows the use of internet in learning physics. Mubarrak (2009) found that web-based learning can improve the generic science skills of high school students. In addition web-based physics learning can enhance students' mastery of the concept of prospective teachers on the material of thermodynamics (Darmadi, 2007). Therefore, it is possible to develop interactive multimedia which is presented by online method.

This research aims to develop interactive multimedia which is presented by offline or online method so that can be improving generic science skills of prospective teacher when learning physics. Online interactive multimedia will be adopting the characteristics offline multimedia and web based learning (e-learning).

\section{Research Method}

The research use quasi experimental method with non-equivalent control group design. The data were collected through tests of generic science skills. This research was conducted at two locations. For investigate the effect of offline interactive multimedia involve the prospective teachers on the department of engineering education of one the university in Bandung. While for investigate the effect of online interactive multimedia involve the prospective teachers on the department physics education of one university in Bengkulu.

\section{Research Results}

\section{Description of Improvement Generic Science Skills of Prospective Teacher Through Offline Interactive Multimedia}

The percentage of the average scores pre-test, post-test and N-gain for generic science skills are shown in Figure 1. 


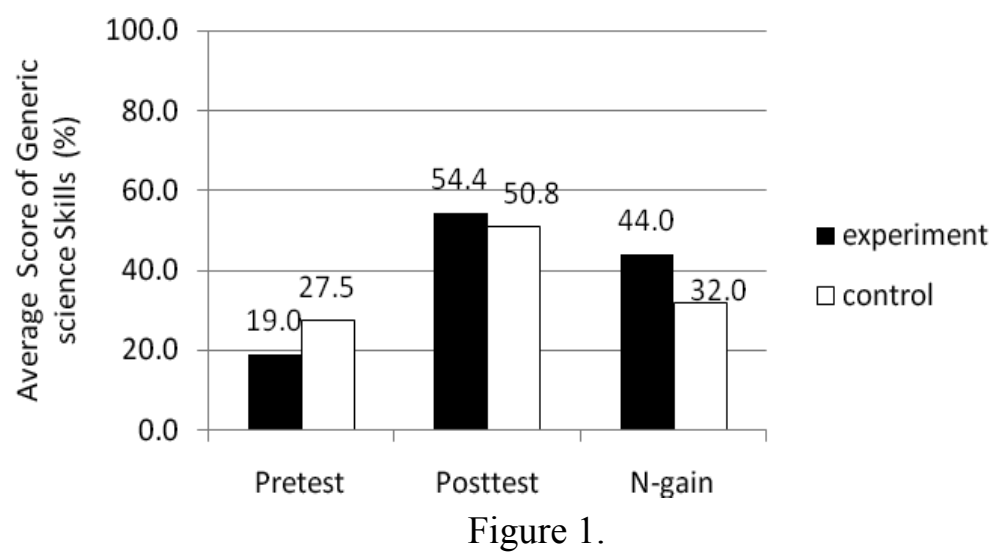

Profile of Generic Science Skills of Prospective Teacher through Offline Interactive Multimedia

The amount of increase in generic science skills, we can compare the average of the $\mathrm{N}$-gain in both classes. The average of $\mathrm{N}$-gain for each indicator of generic science skills can be shown in Figure 2.

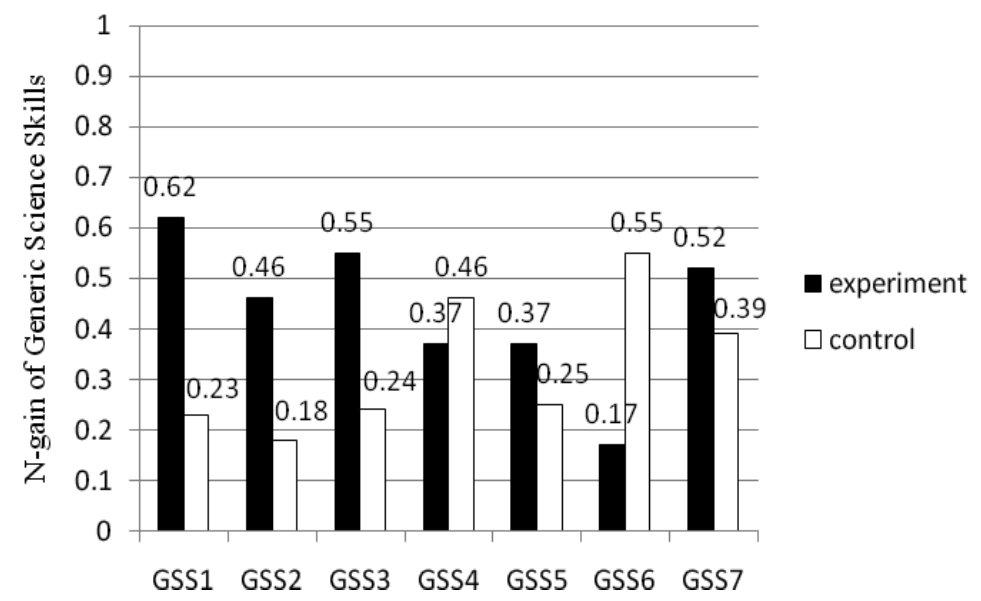

Description : GSS1 = indirect observation; GSS2 = Awareness of magnitude scale; GSS3 = consistently logical framework; GSS4 = logical inference; GSS5 = Causality; GSS6 = mathematical modell; GSS7 = concept development

Figure 2.

Comparison of N-gain Generic Scince Skills for Each Indicator between Experimental and Control Class

The average of $\mathrm{N}$-gain for experimental class of 0,44 (medium) and for control class is 0,32 (medium). From the results of two independent samples $t$ test using SPSS 16.0 with $\alpha=0,05$ show that there are significant differences between the generic scince skills experiment class and control class based on the value of the P-value $=0,000$. This indicates that the use of offline interactive multimedia was significantly superior in improving generic skill better than students who learn with conventional models. 


\section{Description of Improvement Generic Science Skills of Prospective Teacher Through Online Interactive Multimedia}

The percentage of the average scores pre-test, post-test and $\mathrm{N}$-gain for generic science skills are shown in Figure 3.

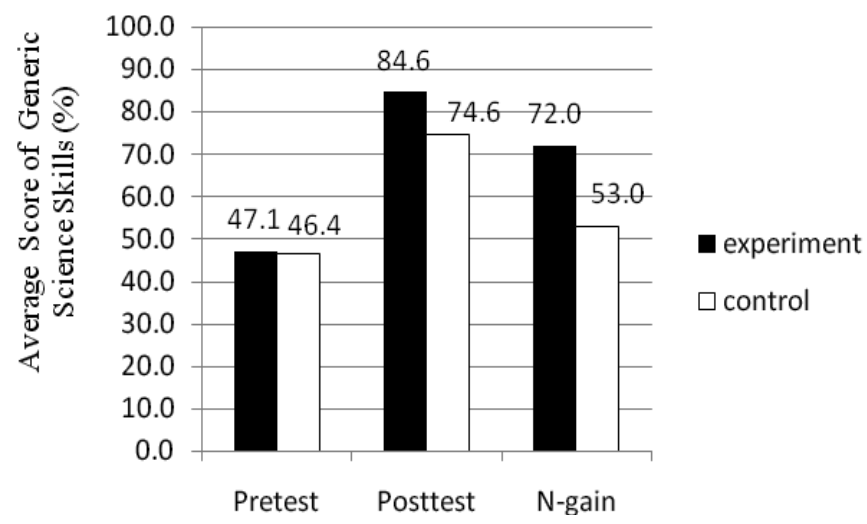

Figure 3.

Profile of Generic Science Skills of Prospective Teacher through Online Interactive Multimedia

The amount of increase in generic science skills, we can compare the average of the $\mathrm{N}$-gain in both classes. The average of $\mathrm{N}$-gain for each indicator of generic science skills can be shown in Figure 4.

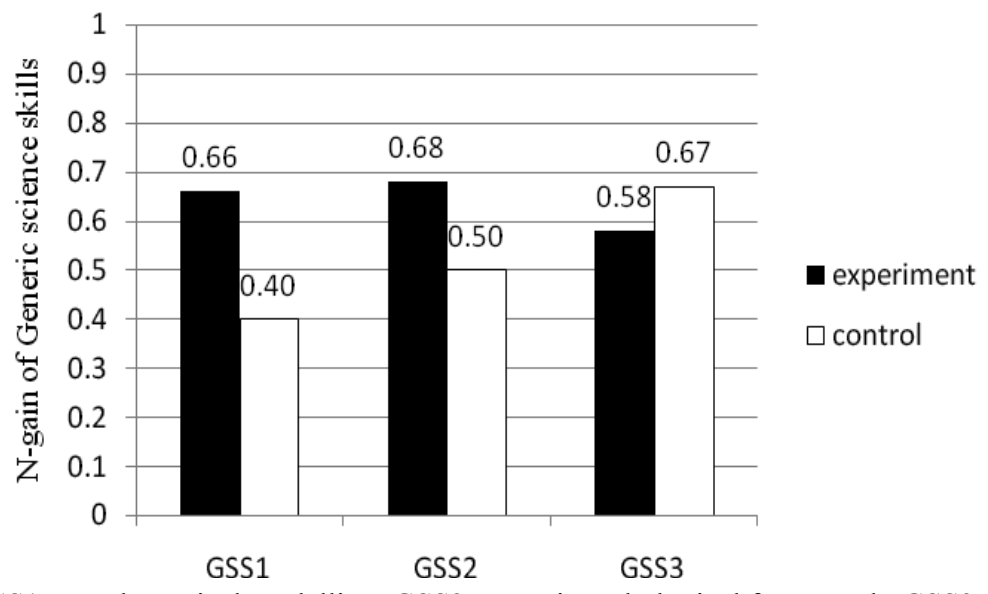

Description : GSS1 = mathematical modelling; GSS2 = consistently logical framework; GSS3 = Causality

Figure 4. Comparison of N-gain Generic Skills for Each Indicators between Experimental and Control Class

The average of $\mathrm{N}$-gain for experimental class of 0,72 (high) and for control class is 0,53 (medium). From the results of two independent samples t test using SPSS 16 with $\alpha$ $=0,05$ shows that there are significant differences between the generic skills experiment 
class and control class based on the value of the P-value $=0,000$. This indicates that the use of online interactive multimedia was significantly better in improving generic skill than students who learn with conventional models.

\section{Discussion and Implications}

Generally the use of offline and online interactive multimedia in learning physics can significantly improve the generic science skills of prospective teacher compared with conventional model. Interactive multimedia emphasize to individual learning so that students can actively construct their own knowledge. In this research, the offline interactive multimedia has been designed based on the syntax of empirical abductive that consists of the exploration phase, introduction concept and application of concepts (Lawson, 1988). While online interactive multimedia which developed combines offline interactive multimedia with e-learning based on development module which presented interactively for example interactive discussion forums, chats, emails, there are links from another parts of the text to clarify the understanding of students, there download facility, and as well as links to another web that is support to learning. Online Interactive multimedia is a pilot project in the research model of IT-based learning model, so that this pilot project focused on three indicators of generic science skill; 1) mathematical modelling, 2) consistently logical framework 3) Causality.

The existence of an interactive simulation allows students to explore the material more deeply at the beginning of learning, observing indirect physical symptoms that occur, observing the relationship between physical quantities with others. Some of the questions given expected to be guiding the process of exploration undertaken by the students became more focused. The questions were prepared based on the exploration of important concepts that must be mastered by students. Therefore, the generic science skills of prospective teacher through offline interactive multimedia in experiment class for indicators other than indicator of the ability of mathematical models more increased compared to the control class. Likewise with online interactive multimedia, generic science skills of prospective teacher unless indicator of causality is more improved compared with the control class.

On mathematical modelling indicator through offline interactive multimedia, the average $\mathrm{N}$-gain for the control class $(0,55)$ is higher than the experimental class $(0,17)$. It is able to understand a mathematical model required a good understanding of the principles and laws of physics. On the offline interactive multimedia which has used in this research, the derivation in is listed in detail. However, to understand the derivation of mathematical equations is still needed an explanation from the lecturer and was given in stages so that students know where the origin of these mathematical models. In the control class, in addition to mathematical models contained in the power point slides, lecturers also provide explanations for the origins of these mathematical models. In addition, the skills of the students' mathematical modelling (data captured using pretest) in the control class higher than students in classroom experiments. While to be able to learn well needed a enough prior knowledge were (Hartono, 2006). For this reason, it is possible that the ability of a mathematical modelling of control class was better than the experimental class. While in online interactive multimedia, students can open the other web links that provide similar learning materials so students can obtain more 
information than students who study them offline. In addition, the chat facility, email can provide convenience to the students to communicate with teachers. Therefore, an online interactive multimedia can further enhance the ability of mathematical models compared with the control class.

The advantages of offline and online interactive multimedia in this research are; 1) student centred learning, 2) student activities can be controlled, 3) the students have the facility to repeat material when need it; 4) interactive simulation is equipped with a few questions so that the exploration process becomes more focused of materials, 5) providing the introduction of symbols that can be viewed at any time during the learning process took place; 6) there is a virtual laboratory that equipped with a table of observations and questions so that they can train students to collect data and make a conclusion, 7) given attention to the speed of the individual to learn, 8) created an interactive evaluation which can give response to any given student answer, 9) In general for offline interactive multimedia, the material presentation follows the syntax of the learning cycle teaching model empirical-abductive; while online interaractive multimedia has combined the characteristic offline interactive multimedia with e-learning; 10) Online interactive multimedia give opportunity for student to download and study the relevant material from another web-links that can enhance the mastery of the material being studied; 11) with online interactive multimedia, the student can still build the interaction with professors and also with fellow students if learning is done outside the classroom through discussion rooms, chat, email, and so forth, 12) Online interactive multimedia give attention for students who are slow learners, because the They can learn anywhere, anytime and anywhere as long as it still can access the internet, but also can boost the effectiveness of learning for students more quickly (fast learner).

As for some of the weaknesses of interactive multimedia which used in this research are; 1) some students are not accustomed to learning independently and still depend on what is given by the lecturers; 2) offline interactive multimedia used less to give emphasis on mathematical models, so that cause the ability of mathematical modelling poorly trained when students learn with offline interactive multimedia; 3 ) in offline interactive multimedia, the concepts application still presented unlimited only on physics problem solving exercises; 4) Some students have not been able to operate a computer and have not good understanding the internet usage. 5) Inadequate computer facilities and internet services in research sites because the computer is usually only used in the laboratory of ICT or related subjects with computer applications.

\section{Conclusion}

The use of interactive multimedia in physics learning which is presented by offline or online method are significantly more able to improve the generic skills of prospective teacher than learning physics with conventional model.

Online interactive multimedia can be constructs by combining the characteristics of the offline interactive multimedia with e-learning or web-based learning. 


\section{References}

Brotosiswoyo, B. (2000). “Hakikat Pembelajaran Fisika di Perguruan Tinggi”, dalam Hakikat Pembelajaran MIPA dan Kiat Pembelajaran Fisika di Perguruan Tinggi. Jakarta: PAU-PPAI UT.

Cheng, K.K., et.al. (2004). “Using Online Homework System Enhances Student Learning of Physics Concepts in an Introductory Physics Course". American Journal of Physics. 72, (11), 1447-1453.

Costa, A. (1985). Developing Minds. Virginia: Association for Supervision and Curriculum Development.

FCIT. (2010). Multimedia in The Classroom. [Online].

Fraenkel, Jack R \& Wallen. 2008. How to Design and Evaluate Research in Education. New York : McGraw Hill

Gunawan, dkk. (2008). Model Pembelajaran Berbasis Multimedia Interaktif untuk Meningkatkan Penguasaan Konsep Calon Guru pada Materi Elastisitas. Jurnal Penelitian Pendidikan IPA. Vol 2 (1), 11-22.

Hartono. (2006). Pembelajaran Fisika Modern bagi Mahasiswa Calon Guru. Disertasi Doktor pada SPs UPI: tidak diterbitkan.

Hoban, G dan Ferry, B. (2006). Teaching Science Concepts in Higher Education Classes with Slow Motion Animation (Slowmation). [Online]. Tersedia: http://edserver2. uow.edu.au/ ghoban/CITE_Garry/docs/ELearnConferencePaper.pdf.

Darmadi, I.W. (2007). Model Pembelajaran Berbasis Web Untuk Meningkatkan Penguasaan Konsep dan Keterampilan Generik Sains Calon Guru pada Materi Termodinamika. Tesis Program Magister Pendidikan IPA SPs UPI Bandung: Tidak diterbitkan.

Ornek et all .(2008). What Makes Physics Difficult. International Journal of Environmental \& Science Education, ISSN 1306-3065

Lawson, A. (1988). Science Teaching and The Development of Thinking. California. W Publishing Company.

Mubarrak, L. (2009). Model Pembelajaran Berbasis Web Pada Materi Fluida Dinamis untuk Meningkatkan Penguasaan Konsep dan Keterampilan Generik Sains Siswa. Tesis Program Magister Pendidikan IPA SPs UPI Bandung: Tidak diterbitkan.

Wiyono, K (2009). Penerapan Model Pembelajaran Multimedia Interaktif untuk Meningkatkan Penguasaan Konsep, Keterampilan Generik Sains dan Berpikir Kritis Siswa SMA Pada Topik Relativitas Khusus. Tesis Program Magister Pendidikan IPA SPs UPI Bandung: Tidak diterbitkan.

Yahya. (2008). Model Pembelajaran Multimedia interaktifoptikfisis untuk Meningkatkan Penguasaan Konsep, Keterampilan Generik Sains, Berpikir Kritis Guru Fisika. Tesis Program Magister Pendidikan IPA SPs UPI Bandung: Tidak diterbitkan. 